\title{
Non-Destructive Measurement of a Combinatorial Materials Library for All-Oxide Solar Cells
}

\author{
C. Lang ${ }^{1}$, S. Rühle ${ }^{2}$, A. Y. Anderson ${ }^{2}$, A. Zaban ${ }^{2}$, P. Statham ${ }^{1}$ and S. Burgess ${ }^{1}$ \\ 1. Oxford Instruments NanoAnalysis, Halifax Road, High Wycombe, HP12 3SE, UK. \\ 2. All-Oxide Photovoltaics Project, Bar Ilan Center for Nanotechnology and Advanced Materials, \\ Bar Ilan University, Ramat Gan 52900, Israel.
}

In this paper we demonstrate the non-destructive measurement of the composition and thickness of a multilayer sample using Oxford Instruments AZtec LayerProbe software [1]. The sample is an all-oxide solar cell structure [2]. The all-oxide photovoltaics approach is very attractive due to the chemical stability, nontoxicity, and abundance of many metal oxides that potentially allow manufacturing under ambient conditions. The sample investigated here consists of a glass substrate, a transparent conductive oxide (TCO) layer (Fluorine doped $\mathrm{SnO}_{2}$ ), and as the active layers, a $\mathrm{TiO}_{2}$ layer with a constant thickness gradient and a top layer with varying $\mathrm{Cu}_{\mathrm{x}} \mathrm{Ni}_{\mathrm{y}} \mathrm{O}_{\mathrm{z}}$ composition and thickness. By varying the thickness of the $\mathrm{TiO}_{2}$ layer and the thickness and composition of the $\mathrm{Cu}_{\mathrm{x}} \mathrm{Ni}_{\mathrm{y}} \mathrm{O}_{\mathrm{z}}$ layer on the same sample it is possibly to create a combinatorial library of PV devices [2], each with a unique combination of active layer composition and layer thickness. To complete the device structure, a top metal contact layer can be deposited which for the purpose of this work was omitted.

In order to characterize layers in the sample non-destructively we acquired a series of 208 EDS spectra from the top of the sample over an area of $42 \times 36 \mathrm{~mm}^{2}$. The LayerProbe software was used to process the spectra. It refines a starting model of the layered structure against the EDS spectra to calculate the film thickness and composition of the layers. The starting model comprises the layer sequence in the sample and the composition of the glass $\left(\mathrm{SiO}_{2}\right), \mathrm{SnO}_{2}$ and $\mathrm{TiO}_{2}$. We confirmed from test samples that the composition of the $\mathrm{SnO}_{2}$ and $\mathrm{TiO}_{2}$ layers were stoichiometric. Therefore, for the $\mathrm{TCO}$ and $\mathrm{TiO}_{2}$ only the thickness was measured, whereas for the top $\mathrm{Cu}_{\mathrm{x}} \mathrm{Ni}_{\mathrm{y}} \mathrm{O}_{\mathrm{z}}$ layer both thickness and composition were determined.

Figures 1(c) to (f) show the results of the thickness and composition measurements. The thickness of the TCO layer is constant across the area measured. The measurements shows that the thickness of the $\mathrm{TiO}_{2}$ layer varies linearly along the horizontal axis whereas the thickness of the $\mathrm{Cu}_{\mathrm{x}} \mathrm{Ni}_{\mathrm{y}} \mathrm{O}_{\mathrm{z}}$ layer has a more complex profile which corresponds to the shading which can be seen in the photograph of the sample in figure 1 (b). Interestingly, the $\mathrm{Cu} / \mathrm{Ni}$ ratio varies significantly, from a $\mathrm{Cu} / \mathrm{Ni}$ ratio of around 1 to almost pure $\mathrm{Cu}$ in the thicker regions of the $\mathrm{Cu}_{\mathrm{x}} \mathrm{Ni}_{\mathrm{y}} \mathrm{O}_{\mathrm{z}}$ layer.

It is anticipated that the combination of the structural information provided by LayerProbe with electrooptical characterization of individual solar cell devices will aid the rapid identification of new materials for solar cells and other applications where a rapid screening of new materials combination is necessary. 


\section{References:}

[1] P J Statham, IOP Conf. Ser. Mater. Sci. Eng. 7 (2010), p. 2027.

[2] S Rühle et al, J. Phys. Chem. Lett. 3 (2012) p. 3755.

[3] The authors acknowledge funding from the European comission under the FP7 AllOxidePV project

"Novel Composite Oxides by Combinatorial Material Synthesis for Next Generation All-Oxide-

Photovoltaics" number 309018 and from the Israeli Focus Technology Area Project "Nanostructured Oxides for Quantum Conversion of Solar Energy" for the development of the solar cell structure.

(a)

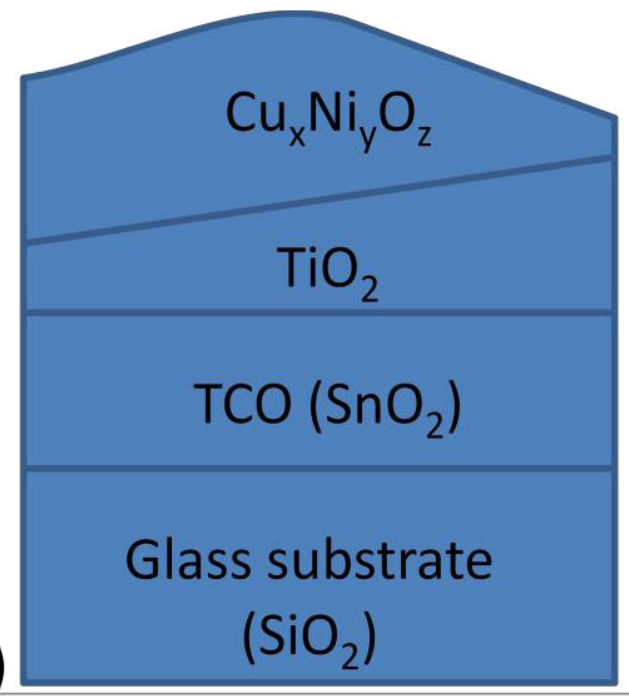

(c)

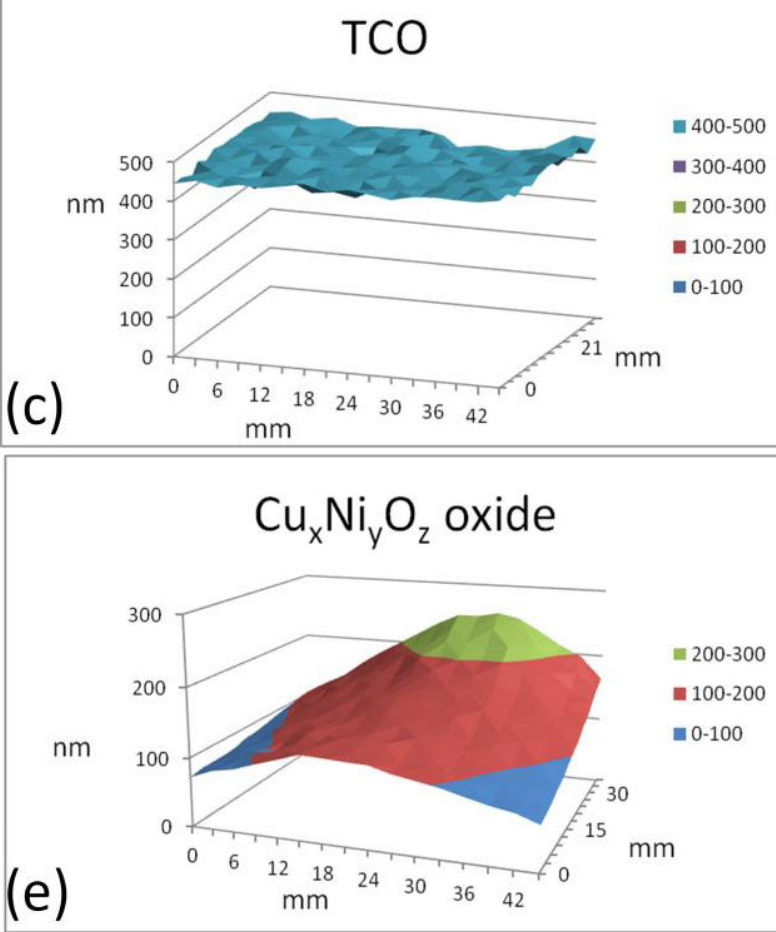

(b)
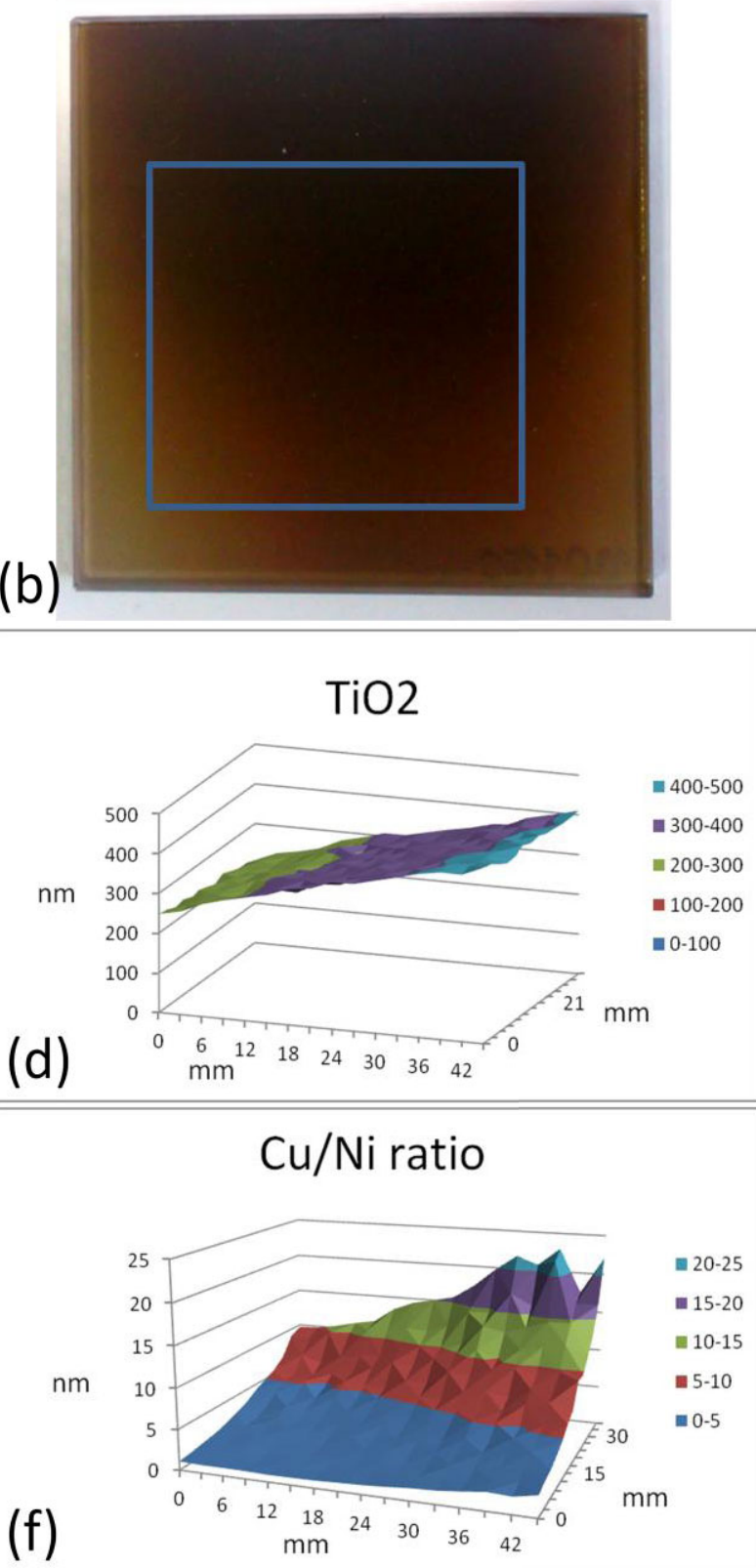

Figure 1. (a) shows the layers in all-oxide solar cell stack, (b) shows a photograph of the sample with the analysed area indicated by the rectangle. The surface plots in (c), (d) and (e) show the layer thickness of the TCO layer, the $\mathrm{TiO}_{2}$ layer and the $\mathrm{Cu}_{\mathrm{x}} \mathrm{Ni}_{\mathrm{y}} \mathrm{O}_{\mathrm{z}}$ layer respectively and (f) shows the $\mathrm{Cu} / \mathrm{Ni}$ ratio in the $\mathrm{Cu}_{\mathrm{x}} \mathrm{Ni}_{\mathrm{y}} \mathrm{O}_{\mathrm{z}}$ layer. 